\title{
The Translating of English Extraposition Constructions into Azeri
}

\author{
Parisa Farrokh \\ English Translation Department, Lahijan Branch, Islamic Azad University, Lahijan, Iran \\ Email: p_farrokh@yahoo.com \\ Abolfaz Rajabli \\ General Linguistics Department, Baku State University, the Republic of Azerbayjan
}

\begin{abstract}
The aim of the research is to run the gamut of English extraposition constructions involving copular verbs, followed by "that-clause" and infinitive. Providing some evidence of the use of these constructions and comparing their translation in Azeri and investigating of linguistic properties are the purposes of this study. To this aim, the English fictions and their Azeri translations considered as sources of the data. The researcher classifies the data into two main categories: the extraposition constructions followed by "that"-clause and the extraposition constructions followed by" infinitive". Based on 200 data, it has been cleared that in Azeri, the dummy subject "it" is not translated at all. Moreover, instead of copular verbs in Azeri translation, there are some expressions called "modal words", functioning like verb phrases, are used according to the meaning of copular verbs. The total number of these sentences using modal words, is 185 sentences. Regarding extraposition constructions followed by that-clause, it can be said that most of them translated as complex sentences in Azeri, with the percentage of $\mathbf{7 0 \%}$. However, extraposition constructions which involve infinitive, are translated as simple sentences. The infinitive is not translated as infinitive in Azeri. The percentage of these sentences is $65 \%$. This study uses a qualitative descriptive method.
\end{abstract}

Index Terms - the Azeri language, translation, translation problems, dummy subject, extraposition

\section{INTRODUCTION}

Nowadays there is a tremendous interest in translation, since it is a channel through which ideas and cultures pass. In more recent time, translation comes to play a significance role in the politics, public and private organizations and many other aspects. It can be said that translation is a profession besides being art. According to Hatim and Munday (2004, p.38) translation is a phenomenon that has a huge effect on everybody's life. Newmark defines translation as the attempt to produce approximate equivalence or respectable synonymy between two chunks of different languages on various levels of which two main ones are thought and linguistic form. Newmark adds that translation is partly an exercise in the art of writing as well as a field of comparative applied linguistics (1988, p.26). Newmark believes that grammatical meaning is more significant, less precise, more general and sometimes more elusive than lexical meaning (ibid). Basically, it will have attained this fact that syntactic differences existing among languages, may cause problem in translation. Here it seems necessary to mention some characteristics of the Azeri language generally, which differ from English and should be considered in order to produce an acceptable translation.

The Azeri language, which is also known as Azeri, Azeri Turkish and Azerbaijani, is the Republic of Azerbaijan's officical language, though some dialects of the language are spoken in several parts of Iran. The Azeri language can be heard in parts of eastern Turkey, northern Iraq, and in southeastern area of the Republic of Georgia. Worldwide, there are about 27 million native speakers of this language. The Azeri language is derived from the Oghuz family of languages and linguistically, it is most closely related to Turkish, Persian and Arabic. As part of the Oghuz family of languages, it was brought from central Asia by Seljuk Turks and in the Middle East it was greatly influenced by the vocabulary and grammar of Persian and Arabic. Eventually, it replaced Tat, Old Azeri and Middle Persian in Iran and became the most dominant language in a multi-lingual area by the 1500s.

Regarding the grammar of Azeri, it can be said that it is an agglutinative language and frequently uses affixes and specifically suffixes. Most of them indicate the grammatical function of the word. Word order in Azeri, is generally subject-object-verb as in Korean and Latin but unlike English. In more complex sentences, the basic rule is that the qualifier precedes the qualified; this principle includes, as an important special case, the participial modifiers. The definite precedes the indefinite. It is possible to alter the word order to stress the importance of a certain word or phrase. The main rule is that the word before the verb has the stress without exception. Moreover as Azeri is a pro-drop language, the subject may not be mentioned in the sentence. The translating of English extraposition constructions involving copular verbs, followed by that-clause and infinitive, into Azeri is the aim of this paper. Since the syntactic pattern of Azeri and English is completely different in this respect, the translation of these constructions may cause some problems for Azerbaijanian translators, translator trainees and English learners. So having complete knowledge 
about structure of these sentences may be useful for them. As Miremadi believes that all languages show signs of noun phrases, events, prepositional phrases and etc but they show differences in their formal distributions (1991, p.67). Nida argues that" in no two languages one can find exactly identical systems of structural organization based on which symbols can be related to meaning on the one -to -one correspondence basis"(1975,p.24). According to Nida word classes, grammatical relations, word order, style and pragmatic features are different from language to language (ibid). A feature which may cause problem in translation is English extraposition constructions. Since based on Chocholoušova's research, among the constructions involving dummny subject, extraposition constructions are the most frequent type in materials in languages like English, Norwegian and German, therefore, it seems necessary to have complete knowledge about this construction and it's translation in Azeri (2007, p.49). To this end English fictions are studied to identify these structures in English and their Azeri equivalents. In this relation, the following research questions have been formulated: how are English extraposition constructions translated into Azeri? Is English dummy subject "it" kept/replaced or omitted in Azeri translation?

\section{TRANSLATiOn AND TRANSLATION Problems}

Translation is a process aimed at facilitating communication between speakers of different languages. Translation implies understanding the source text and this requires knowledge of the specific terms of the source and target languages. A good translation not only has to express the same content as the source text but it has to do so in the forms that a native reader of the target language would use. Therefore the production of translation is based on the translators' careful assessment of the recipient and the purpose of the target text. The translator makes the decision about translation strategy and treatment of source terminology and syntactic structures proceeding from the study of parallel texts, terminological sources like dictionaries, databases and so on. It can be said that because of translation's intricate relationship with natural languages, the knowledge and skills of professional translator have always been particularly dependent on many variables and norms ranging from linguistic to socio-cultural ones. Translation, in other words, is the constructive shaping of a multi-medial situation as a whole, since in fact the translator's main responsibility is to provide for situationally appropriate communicative artifacts (Risku, 2002, p.526).

According to Nida (1975) "translation is the reproduction in a closest natural equivalent of the source language message". It means that a translation should tell the content and some meaning of the original text (p.41).

Translation itself means a process of replacing/reproducing/transferring from the source language of written text/material concept into it's target language (Karnadidjaya, 2001, p.4). Wilss believes that translation is a transfer process which aims at the transformation of a written source language into an optimally equivalent target language and which requires the syntactic, semantic and pragmatic understanding and analytical processing of the source language. Generally, it can be said that in the present era of globalization, translation plays a major role in conveying messages from one language to another. However translation is not an easy task. Since languages express grammatical and lexical relationships in different ways, therefore, in rendering texts, the translators are always surrounded by a number of problems which are to be tackled consciously and accurately. Miremadi believes that the first problem is how to get access to adequate comprehending of the original text with all it's complexities (1992, p.98). According to Kopezynski (1980) as cited in Miremadi, the translator should possess a transcoding mechanism to enable him:

a. to make accurate interpretation of the totality of the source and target language.

b. to carry out an adequate conversion of the source language grammar into the target language grammar.

c. to make generalization based on intertraffic between the two languages to seek equivalents.

The second problem is the existence of lexical, syntactic, semantic, pragmatic and the word perspective imbalance between languages. Because of differences between languages, there is no completely exact translation between any two languages. According to Werner (1975) as cited in "Golestani", the degree of similarity between the systems of any two languages determines the efficacy of the translation made".

The other problem in translation is lexical problem. Words are entities which refer to object or concepts.

There is no an identical object in the two cultures. Thus in translating texts, all differences have to be taken into account and must be considered as an important factor. In this case the denotative meaning, connotative meaning and ironical meanings are so important and translator's misunderstanding of any of these words and elements may end in a translation reality and moral sense.

Another factor which may cause problem in translations is syntactic problem. It can be said that syntax is the study of the rules to form or to make grammatical sentences in a language or the study of pattern of sentences and phrase formation from word (Yerkes, 1989, p.1443). Furthermore, grammar is studied in syntax and it is an important aspect of a language. According to Hornby, grammar is defined as the rules in a language for changing the form of words and combining them into sentences (1995, p.517). Every language has own grammatical rules and through contrastive studies of authentic syntactic patterns in context, new possibilities open up for additional insights, methodological renewals and empirical theory developments based on the study of sentence form. As Hunston\&Sinclair put it:

"There are gaps in the coverage of grammatical structures achieved by a generalisable system of structural analysis..." (2000, p.75).

Basically, grammar and translation skill are very important in learning another language. Some differences of grammatical systems between two languages can cause problem in translation process. 


\section{DumMY SUBJECT}

The concept of subject originally came from the study of Indo-European language family. Subject is obligatory in English with the exception of imperatives, and it plays syntactic and semantic roles, or just syntactic role as in the case of dummy subjects. In contrast, subject may be optional as in pro-drop languages such as Azeri, Persian and etc. "It" as a dummy subject, it is semantically empty, has no referential function, no referent either in the discourse context or in the outside world. No thematic role can be assigned to it, and yet it keeps the most prominent thematic position of the sentence, i.e. the one of a subject. And to complicate things even further, no informative value or pragmatic prominence is directly encoded in the presence or absence of the dummy subject (Chocholoušova, 2007. p.27).

Biber et al (1999) identifies both semantically empty "It" and referentially empty" there"as formal grammatical subjects that appear in specific clause types. These are as follows:

1. prop it- denoting weather distance and time.

It starts rainig.

2. Existential clauses- (i.e. presentatives) - introducing new information, and using verbs denoting existence, appearance and motion.

There are flagstones, garden gates, hedges, garages.

3. Clefting- structural clause division that brings focus to the clefted element.

It's mostly just rich folks who can afford a movin company.

4. Extraposition - clauses where dummy subjects anticipate another finite or non-finite clause.

It takes a great effort to watch the moon for any length of time.

Biber et al. postulates that:

"[...] the predicates here do not suggest any participant involved semantically, but [...]are obligatory inserted simply to complete the structure of the clause grammatically".

Existential clauses, or presentative constructions, are the only constructions types that employ existential there as their formal, grammatical subject; the others use" it". So is the case of "agentless processes "that are not listed in Biber et al., nevertheless structurally possible in English:

It does not smell particularly great at Grandfather's.

The only exception here are "impersonal passives" that are structurally not allowed to be formed with intransitive verbs in English, hence, another types of subject must be inserted.

\section{EXTRAPOSITION}

Posponement which involves the replacement of the postponed element by a substitute form is termed extraposition. It operates almost exclusively on subordinate nominal clauses. The most important type of extraposition is that of a clausal subject- i.e. a subject realized by a finite or non-finite clauses (Quirk et al, 1985, p.1391). According to Quirk et al, the subject is moved to the end of the sentence and the normal subject position is filled by the anticipatory pronoun"it". The resulting sentence thus contains two subjects, which may identify as the postponed subject, the one which is notionally the subject of the sentence and the anticipatory subject "it". Simple rule for deriving a sentence with subject extraposition from one of more orthodox ordering is: Subject + predicate $\sim$ it+predicate + subject Thus:

To hear him say that +surprised me $\sim$ It + surprised me + to hear him say that Some examples of this construction are shown as follows:

Type SVC: It is a pleasure to teach her.

Type SVA: It was on the news that income tax is to be lowered.

Type SV: It does not matter what you do.

Type SVO: It seems that you have made a mistake.

Type SVOC: It makes him happy to see others enjoying themselves.

Type SV pass: It is said that she slipped arsenic his tea. (ibid).

Herriman (2004, p.204) argues that the extaposition constructions are mainly used to express attitudinal meaning. In this research the Azeri translation of English extraposition constructions involving copular verbs, followed by that clause and infinitive has been investigated.

\section{RESEARCH METHOD}

The purpose of this study is to investigate and analyze Azeri translations of English extraposition constructions involving copular verbs, followed by that -clause and infinitive. This research deals with analyzing of data in order to study Azeri translations of dummy subject it, infinitive and that-clause of English extraposition constructions.

\section{A. Materials}

The materials chosen for the analysis are English fictions which involve the novels of "For Whom the BellTolls" written by Hemingway, "400 Subjects in English" written by Vitalyevna, "Life Essays" written by Gurbanov, "The Alchemist" written by Coelho and Joyce's Dubliners (short stories). 200 extraposition constructions involving copular 
verbs, followed by infinitive and that - clause along with their translations into Azeri taken from Hajiyev (2006), Vitalyevna (2006), Gambarov (2010), Qojabayli (2006) and Nijat (2011) have been analyzed.

\section{B. Procedures}

The data are classified into two main categories: extraposition constructions followed by infinitive and extraposition constructions followed by that- clause.

\section{Extraposition Constructions Followed by Infinitive}

The constructions which are translated as simple sentences without infinitive in Azeri

- They seemed to be a happy couple at first.

əvvəlcə elə bil xoşbəxt cütlük idilər.

- It seemed to him to repeat itself throughout all the books.

Sanki bütün kitablarda elə hey eyni şey təkrarlanı rdı r.

- It seems to me to remember things incorrectly.

məncə hər şeyi yaxşı saxlaya bilməmisəm.

- It seemed to him to admire the horses.

Sanki atları torifləmolidir.

- It seems to me to know everything is useful for you.

elə bil hər şeyi bilməin sənə faydalı dı $\mathbf{r}$.

- It wonders me to see a gypsy a war.

məncə qaraçı müharı bədə görməini । nanı lası şey dir.

- It seems to agree with you.

görünür sənən şərik olmalı dı r.

- It seems to be sensitive and kind.

görüiür həssas və yumşağ adam dı $\mathbf{r}$.

-It sounds me to be interesting.

nə isə elo bil maraqlı dı $\mathbf{r}$.

- It seemed to him to be little better guarded.

Görünür düşərgənin müdafiəsi yaxşı təşkil olunmayib.

The constructions which are translated as simple sentences and involving infinitive in Azeri

- It pleases thee to carry it, he said.

I ndı ki dașmaq istəyirsən ,al... dedi.

- It seems to the boy to flee.

ağ lı na qacmaq gəlmișdi.

- It seems to me to exterminate the post at the sawmill.

məncə taxta zavodundakı postu məhv etmək lazı mdı r.

- It seemes to him to go out.

görünür cı xmaq lazı mdı r.

- It seems to keep down is the best.

görüiür uzanmaq yaxşı dı r.

D. Extraposition Constructions Followed by That-clause

The constructions which are translated as complex sentences in Azeri

- It seems to me that we might as well eat the hares.

mənə görünür ki dovșanları isə bu gün yemək lazı mdı r.

- It sounds me that it would be good to see Duran again.

yaxşı olardı ki Dürana bir də görüşəydim.

- It seems that you have an important intention.

görünür ki sənin belə bir mühüm niyyətin var.

- It seems that it is allright to stay here.

görünür ki burada qalmaq daha yaxşı dı $\mathbf{r}$.

- It wonders me that the old swine will go.

maraqlı dı r görəsən bu donuzoğ lu hara gedir.

- It wonders me that one pays as in the days of the church.

maraqlı dı r ki biz kilsəyə pul verdiyimiz kimi,haqq versinlər.

- It seems that the Respublic is preparing an offensive.

görünür ki Respublika hücüma hazirlaşı r.

- It seems that I am barbarous.

görünür ki vəhşiyəm.

- It wonders me that he might not understand.

maraqlı dı r ki məni başa düşməz. 
- It seems that I can never bear either a son or a daughter. görünür ki sənə oğ lan və ya qı z doğ a bilməyəcəyəm.

The constructions which are translated as simple sentences in Azeri

- It seems to me that it is better not to speak of it.

məncə bu barədə danı şmasaq yaxşı dı r.

- It seems that she is perfectly normal.

elo bil onda eybi yoxdur.

- It sounds me that it is interesting.

elo bil maraqlı söhbətdir.

It seemed to him that they laugh at him.

elə bil Ehramlar ona gülümsədilər.

- It seemed to him that he had made the long journey for nothing.

deməli boş yerə səyahətə çı xmı şdı .

The constructions in which copular verbs have not translated in Azeri

- It sounds me that I am not good to receive thee as I wish to.

$\varnothing$ səninlə istədiyim kimi ola bilməyəcəyəm.

It seemed to him to see stars on the desert itself.

Ø səhranı nı n səması nda yüzlərcə ulduz parlayı dı .

It seemed to him that time stood still.

$\varnothing$

kainatı n Rohu cavan oğ lanı n önündü.

It seemed to him to be very busy.

Ø işləri başları ndan aşı rmı ş kimi görünürdülər.

- It seemed to me that you have to cross the entire Sahara desert.

$\emptyset$ böyük saxara səhrası nı keçmək lazı mdı r.

\section{DATA FINDINGS}

In this research, there are two main categories, namely, extraposition constructions followed by that-clause and the other one extraposition constructions followed by infinitive. The analysis of 100 data related to the Azeri translation of English extraposition constructions followed by that-clause shows that most of them are translated as complex sentences in Azeri with the percentage of $70 \%$, and some translated as simple sentences with the percentage of $30 \%$, (table 1). According to table (2) it has been cleared that $65 \%$ English extraposition constructions followed by infinitive, translated as simple sentences without infinitive and 35\% translated as simple sentences involving infinitive in Azeri. Table (3) shows that in Azeri dummy subject is not translated at all. Regarding the translation of copular verbs in Azeri, as shown in table (4), they have either been replaced by some expressions called "Modal Words" or been omitted.

\section{DISCUSSION AND CONCLUSION}

Based on 200 data, it has been cleared that in Azeri, dummy subject of English extraposition constructions is not translated. Regarding copular verbs, it should be mentioned that the copular verb "seem" is the most frequent one in this corpora, that is in 138 constructions this verb has been used. Results of analyzing of the Azeri translation show that instead of copular verbs, there are some expressions in Azeri which are named "Modal Söz"like Görünür, məncə, elə bil ... and according to the meaning of copular verbs, these expressions are used such as görünür ki Respublika hücüma hazirlaşı $\mathbf{r}$. Of course in some cases copular verbs are omitted as in:

- It sounds me that I am not good to receive thee as I wish to.

$\varnothing$ səninlə istədiyim kimi ola bilməyəcəyəm.

Moreover, if there is an object after copular verbs, it is used before modal words, i.e in the beginning of the clause like mənə görünür ki dovşanları isə bu gün yemək lazı mdı r, "mənə" is the object of the sentence.

According to the results of this research, English extraposition constructions followed by that-clause translated as complex sentences as in mənə görünür ki dovşanları isə bu gün yemək lazı mdı $\mathbf{r}$, and in some cases translated as simple sentences such as məncə bu barədə danı şmasaq yaxşı dı r.

Most of the English extraposition constructions followed by infinitive, are translated as simple sentences and without infinitive like əvvəlcə elə bil xoşbəxt cütlük idilər, however it should be mentioned in some constructions, infinitive translated as infinitive in Azeri, as in:

- It seems to me to exterminate the post at the sawmill.

məncə taxta zavodundakı postu məhv etmək lazı mdı r.

It can be concluded that English extraposition constructions can be translated as follows in Azeri :

It + verb $+($ object $)+$ that - clause translated as (object $)+$ modal words + that clause

It + verb $+($ object $)+$ infinitive translated as (object $)+$ modal words + verb.

In this case, as it was mentioned, through contrastive studies of authentic syntactic patterns in context, new possibilities open up for additional insights, methodological renewals and empirical theory developments based on the 
study of sentences form. The main advantage of a bilingual or even multilingual parallel corpus is that the languages interrelate with each other. According to the results of this study, it can be concluded that at the grammatical level, a translator is expected to have a thorough knowledge of the grammatical rules of the target language. In fact, a translator does not have to know the grammar of the language for just the sake of it, he should be well versed in comparative grammar of the two languages involved in translation and the similarities and dissimilarities in them. Therefore, translation is always more than simply writing in the sense of putting words to paper. Risku (2002, p.526) argues that translations are by definition, written for new situations, purposes, recipients and cultures. When you learn to translate, you have to learn how to gain an overview of a new situation with all it's different factors and, perhaps even more importantly, you have to learn how to position yourself in this communication system and define your own situational role, goal and tasks. Moreover, it seems that in the literature of translation studies and in translation classrooms, students and learners are required to compare and contrast translations with their originals. It is useful for language learning, translation education, translation studies, lexicography, finding equivalents for source language expressions, terms, structures and so on. It is hoped that the results of the research may be used as additional information for the teachers especially in teaching English grammar and translation courses. Also, the results may help Azerbaijanian translators, English learners and translator trainees for being able to provide the best translation of English extraposition constructions.

\section{APPENDIX TABLES}

TABLE 1.

THE TRANSLATION OF THE EXTRAPOSITION CONSTRUCTIONS FOLLOWED BY THAT-CLAUSE

\begin{tabular}{|l|c|c|}
\hline & Total & Percentage \\
\hline Complex sentences & 70 & 70 \\
\hline Simple sentences & 30 & 30 \\
\hline
\end{tabular}

TABLE 2.

THE TRANSLATION OF THE EXTRAPOSITION CONSTRUCTIONS FOLLOWED BY INFINITIVE

\begin{tabular}{|l|l|l|}
\hline & Total & Percentage \\
\hline Simple sentences without infinitive & 65 & 65 \\
\hline Simple sentences involving infinitive & 35 & 35 \\
\hline
\end{tabular}

TABLE 3.

THE TRANSLATION OF DUMMY SUBJECT

\begin{tabular}{|l|l|}
\hline & Total \\
\hline TABLE 4. \\
\hline \\
THE TRANSLATION OF COPULAR VERBS \\
\begin{tabular}{|l|l|}
\hline & Total \\
\hline Using modal words & 185 \\
\hline Deletion of copular verbs & 15 \\
\hline
\end{tabular}
\end{tabular}

\section{REFERENCES}

[1] Biber, D., Johansson, G., Leech, S., Conrad, E. \& Finegan, E. (1999). Longman Grammar of Spoken and Written English. (pp. 89-110). London: Longman.

[2] Chocholoušova, B. (2007). Norwegian det-constructions and their translation correspondences in English and German: A contrastive corpus based study of dummy subjects. Master's Diploma Thesis.

[3] Gambarov, V. A. (2010). Life Essays. (pp. 174-288). Baku: Mushfigh Brocjhali Publication.

[4] Golestani, G. (2006). The translating of problems of pro-forms from English into Persian. (p.3). Islamic Azad University Science and Research Fars Branch.

[5] Hajiyev, H. (2006). For Whom the Bell Tolls. (PP. 14-294).Baku: Avrasiya Press.

[6] Hatim,B., \& Munday, J.(2004).Translation: An Advanced Resource Book. London: Routledge.

[7] Herriman, J. (2004). The functions of extraposition in English texts. Amsterdam: John Benjamins.

[8] Hornby, A. S. (1995). Oxford Advanced Learner's Dictionary of Current English. (3 ${ }^{\text {rd }}$ edition). Oxford: Oxford University Press.

[9] Hunston, S. \& Sinclair, F. (2000). Pattern grammar: A corpus-driven approach to the lexical grammar of English. Amsterdam: John Benjamins.

[10] Karnadidjaya, M. (2001). The translation process. Indonesia: National Publication.

[11] Miremadi, A. (1991). Theories and Principles in Translation. Tehran: Samt Publication.

[12] Newmark, p. (1988). A Textbook of Translation. Perntice Hall.

[13] Nida, E. A. (1975). Toward a science of translating: With special reference to principles and procedures involved in Bible translation (2nd ed.). Leiden: E.J. Brill.

[14] Nijat, A. (2011). Dubbliners. (pp. 250-307). Baku: Ghanun Publication.

[15] Qojabayli, N. (2006). The Alchemist. (PP. 8-92). Baku: Chinar Publication. 
[16] Quirk, R., Greenbaum, S., Leech, G., \& Svartvik, J. (1987). A comprehensive grammar of the English language. (5th ed.). London and New York: Longman.

[17] Risku, H. (2002). Situatedness in translation studies. Cognitive systems research No.3.p.526

[18] Vitalyevna, K. Y. (2006). 400 Subjects in English. (pp.152-355). Baku: Sorghu and Encyclopediya Publication.

[19] Wilss, W. (1982). The science of translation: Problems and Methods. (p.41). Tubingen: Gunter Narrvelag.

[20] Yerkes, P. (1989). Teaching and learning a second language. London: Longman.

Parisa Farrokh received her M.A. in linguistics from Shahid Beheshti University, Tehran, Iran. She is currently Ph.D student of linguistics and faculty member of Islamic Azad University of Lahijan Branch, Iran. She has published some books and articles in different countries like Iran, Finland,Canada and Azerbayjan Republic.

Abolfaz Rajabli is the professor of general linguistics department of Baku State University, The Republic of Azerbaijan. He is interested in studying linguistics, translation and teaching. 